\title{
THE EVOLUTION OF THE ENERGY IMPORT DEPENDENCE NETWORK AND ITS INFLUENCING FACTORS: TAKING COUNTRIES AND REGIONS ALONG THE BELT AND ROAD AS AN EXAMPLE
}

\author{
Qingru SUN ${ }^{1,2,3}$, Xiangyun $\mathrm{GAO}^{4}{ }^{*}$, Jingjian $\mathrm{SI}^{4}, \mathrm{Xian} \mathrm{XI}^{4}$, Siyao $\mathrm{LIU}^{4}$, \\ Huiling $\mathrm{ZHENG}^{4}$, Wenting $\mathrm{LIANG}^{4}$ \\ ${ }^{1}$ School of Economics, Hebei University, Baoding, China \\ ${ }^{2}$ Research Center of Resources Utilization and Environmental Conservation, \\ Hebei University, Baoding, China \\ ${ }^{3}$ Institute for Advanced Study of Yanzhao Culture, Hebei University, Baoding, China \\ ${ }^{4}$ School of Economics and Management, China University of Geosciences, Beijing, China \\ ${ }^{5}$ Key Laboratory of Carrying Capacity Assessment for Resource and Environment, \\ Ministry of Natural Resources, Beijing, China
}

Received 22 November 2020; accepted 26 May 2021; first published online 30 November 2021

\begin{abstract}
This paper provides the concept of import dependence between countries, which is a relative quantity. In order to reveal the evolutionary characteristics of the import dependence between countries in energy trade and its influencing factors, firstly, based on the network analysis method, this paper constructs a model of energy import dependence network (EIDN) among countries and regions along the Belt and Road (B\&R countries). Crude oil and natural gas are taken as empirical objects, and the evolution characteristics of the two kinds of EIDNs are analysed. The result showed that most of the B\&R countries had a small number of crude oil and natural gas trade partners. However, the import dependence in crude oil and natural gas trade between countries is relatively large, indicating that the risk of oil and gas security in B\&R countries is high. Moreover, based on the QAP method, spatial distance, economic differences, the signing of free trade agreements, and the differences in energy consumption between countries have a significant impact on the import dependence in crude oil and natural gas trade among B\&R countries.
\end{abstract}

Keywords: energy trade, import dependence, influencing factors, QAP method, network analysis, B\&R countries.

JEL Classification: F02, F14, F52.

*Corresponding author. E-mail: gxy5669777@126.com

Copyright @ 2022 The Author(s). Published by Vilnius Gediminas Technical University

This is an Open Access article distributed under the terms of the Creative Commons Attribution License (http://creativecommons. org/licenses/by/4.0/), which permits unrestricted use, distribution, and reproduction in any medium, provided the original author and source are credited. 


\section{Introduction}

Energy, especially crude oil and natural gas, acts as a driving factor of economic development. The uneven distribution of energy resources and the difference in energy consumption among countries make the energy flows among countries and regions by international trade, causing energy import dependent relationships between importers and exporters. For example, in China, the import dependence on foreign oil and gas increases annually and reached $69.8 \%$ and $45.3 \%$ in 2018 , respectively ${ }^{1}$. Besides, more than $70 \%$ of China's total crude oil and natural gas imports come from the countries and regions along the Belt and Road (B\&R countries). The exporting countries sell energy to collect wealth and improve their economies, while importing countries have energy risk since they depend on foreign energy to support their domestic economy (Li et al., 2015). This interdependence makes importers and exporters interact and restrict each other, thus causing geo-economic and geopolitical effects and increasing restrictions on countries' independence and autonomy. Thus, countries have formed a community of common destiny on energy and economy. The import dependent relationships of energy trade are complicated and form an energy import dependence network (EIDN). Researching the topological structure of the EIDN and its influencing factors is of great significance for the energy security and economic development of countries.

On the one hand, more researchers have focused on energy import security and the pattern of international energy trade (Bigerna et al., 2021; Vivoda, 2019; Sun et al., 2017; Wang et al., 2018). The energy trade relationships among countries form a complex system, which can be acted as an international energy trade network with countries representing nodes, trade relationships representing edges and trade volumes between countries representing edge weights (Sun et al., 2017). Based on the network analysis method (Wang \& Kong, 2019; Liang et al., 2020), the evolution of international energy trade (Geng et al., 2014) and the position of countries in the network (Zhong et al., 2017; Zhang et al., 2021) were revealed. Chong et al. (2019) analyzed the evolution of structural features of the B\&R trade network and found that China, Singapore, Russian Federation, Malaysia and India are in the core position. These studies focused on the trade volumes between two countries from an absolute quantity perspective and revealed that countries with large trade volumes or a large number of trade partners play leading roles in the trade networks. Countries with lots of energy import partners can import different quantities of energy from their partners, spreading their energy import risk. However, if a country has lots of trade partners, but imports a large volume from one partner, then it has high energy import dependence on this partner, causing a high risk of energy security. Specifically, when its partner cuts off the energy supplying suddenly, the economies of the country will be greatly influenced. Thus, it is significant for countries to deepen the understanding of their energy security risk by revealing the import dependence relationships in energy trade among countries, which is still uncovered in former researches. The import dependence in energy trade of country A on country B, as proposed in this paper, is defined as the proportion of the energy volumes of country A importing from country B in the total energy volumes of country A importing from the world, which is a concept of relative quantity.

\footnotetext{
1 The data was obtained from the development report of oil and gas industry in China and foreign countries in 2018.
} 
On the other hand, the studies on the influencing factors of international trade are mainly based on the difference-in-difference model (Xie, 2018) and trade gravity model (SantanaGallego et al., 2016; Spring \& Grossmann, 2016; Wu et al., 2020). They found that the size of the economy, population, culture and trade system have a great influence on international trade. For example, the economic magnitude of a country has a positive influence on the country's energy trade quantities (Matthee \& Santana-Gallego, 2017; Zhang et al., 2018). However, they focused on the determinants of a country's trade volume and ignored the determinants of trade relationships (import dependence relationships) among countries. Besides, what are the determinants of import dependence relationships in energy trade? For example, the spatial distance between exporters and importers can be regarded as a distance relationship and represents the transportation cost, so do the distance relationships between countries hinder the energy import dependence relationships between countries? It is the relationship between two kinds of "relationships", which is a new perspective. This paper focuses on influencing factors of the import dependence relationships in energy trade among countries.

Major changes have taken place in the pattern of international energy trade and energy consumption, especially crude oil and natural gas, and countries in the Asia-pacific region are rapidly overtaking the countries in North America and Europe and becoming the center of global energy consumption. The B\&R countries have gradually become the world's production, consumption and trade centers of crude oil and natural gas. However, the crude oil and natural gas in $B \& R$ countries are not balanced in terms of production and consumption, and supply and demand. Specifically, some B\&R countries, such as Kazakhstan and Russia, have rich resources on crude and natural gas and mainly rely on exporting energy to support their economies. While the crude oil and natural gas resources in some B\&R countries, such as China and Turkey, are scarce, and these countries need importing lots of energy to support their economic development. Therefore, the crude oil and natural gas trade among $\mathrm{B} \& \mathrm{R}$ countries have great significance in their economic development and energy security.

In this paper, the crude oil and natural gas trade among B\&R countries are taken as an empirical object, and the evolution of the oil and gas import dependence pattern and its influencing factors are analyzed. Specifically, this research provides the concept of import dependence between countries. Then, the EIDN among B\&R countries is constructed based on complex network theory. The evolution characteristics of the EIDNs are analyzed from the perspectives of overall network characteristics, the number of importing partners in energy trade and import dependence in energy trade. Furthermore, according to the literature review and data availability, spatial distance (SD), economic differences (ED), free trade agreements (FTA) and differences in energy consumption (ECD) are chosen as influencing factors of the energy import dependence pattern among B\&R countries. Based on the quadratic assignment procedure (QAP) method, the regression results of these factors on the EIDN are analyzed. Finally, this paper provides some policy implications about the energy trade of $B \& R$ countries from the perspective of energy security.

The paper is structured as follows. Section 1 provides the research hypotheses. Section 2 describes the data, the construction of the network model and the network indices. Section 3 shows the results and discussion of the empirical study. The last Section contains the main conclusions and policy implications. 


\section{Research hypotheses}

The gravity equation is commonly used to analyse the determinants of bilateral international trade flows (Chaney, 2018; Duarte et al., 2018; Ho et al., 2020), and the gravity equation in international trade reveals that the total trade between two countries is proportional to their economic size and inversely proportional to their spatial distance. This paper studies the determines of import dependence in energy trade between countries.

Firstly, SD (spatial distance) represents the transportation cost to some extent. The geographical distance between countries has been found that it is a barrier to the imports of products and has a negative influence on trade flow (Kitamura \& Managi, 2017). Chong et al. (2019) revealed the negative impact of SD on the trade relationships among B\&R countries. As for B\&R countries, crude oil and natural gas are mainly transported by sea and pipelines. Thus, the longer the SD between B\&R countries is, the higher the transportation cost and the risk of crude oil and natural gas transportation are. This study assumes that SD hinders the trade between $B \& R$ countries and has a negative impact on the crude oil import dependence (Hypothesis 1) and SD has a negative impact on the natural gas import dependence among $\mathrm{B} \& \mathrm{R}$ countries (Hypothesis 2).

Secondly, the new trade theory regards economies of scale as the key factor driving international trade (Krugman, 1987). In a market with imperfect competition, due to the large demand of the country, the development of industries relies on the effect of the economics of scale and has an advantage in the international trade (Kandogan, 2003). For example, Erdey and Postenyi (2017) analysed the determinants of the exports of Hungary and revealed that economic size had a statistically significant positive effect on exports. Other researchers also found that a country's GDP had a positive influence on trade flow (Shuai et al., 2020). Besides, the economic magnitude of a country is large, meaning that its energy consumption is also large. Zhang et al. (2018) found that liquefied natural gas trade was affected by the economic magnitude of the demand side. Importers rely on energy to support their economies, and exporters need to increase their export volume to gain wealth and improve their economies. Fagiolo et al. (2010) found that high-income countries tend to hold more intense trade relationships with other high-income countries. Thus, this paper assumes that the less the ED (economic difference) between B\&R countries is, the closer the trade link is and the larger the crude oil and natural gas import dependence between $B \& R$ countries is (Hypothesis 3 and Hypothesis 4).

Thirdly, the signing of FTAs (free trade agreements) breaks down trade barriers, lowers the cost of tariffs and expands export among countries, all of which is helpful for the communication of trade members from each country (Petreski, 2013). Some researchers have revealed that FTAs have a significantly positive effect on exports (Aitken, 1973; Matthee \& Santana-Gallego, 2017; Feng et al., 2020). For example, Caporale et al. (2009) focused on FTAs between the European Union and the Central and Eastern European countries and found a positive and significant impact of FTAs on trade flows. Atici and Furuya (2008) verified the significant impact of the trade agreements among the Association of Southeast Asian Nations on agricultural trade flows between Indonesia, Malaysia, the Philippines and Taiwan. Thus, the signing of FTAs among countries can promote the trade flow of products among countries. This paper assumes that the signing of FTAs has a positive influence on 
the crude oil and natural gas import dependence among B\&R countries, respectively (Hypothesis 5 and Hypothesis 6).

Fourthly, the differences in the accumulation of production factors in countries increase the volume of international trade (Balassa, 1979). Armijo (2007) studied the factors impacting energy trade between China and Russia, revealing that the differences in energy resources between the two countries improve their energy cooperation. Besides, China's oil consumption is the main factor affecting China's oil imports. Thus, the uneven distribution of the production and consumption of energy makes the energy flows between countries by international trade. Based on the former studies (Zhong et al., 2016, 2017), the energy trade relationships with high trade quantities exist between countries with abundant energy reserves and countries with high energy consumption. Since it is very hard to obtain the historical data on energy production and energy reserve in $B \& R$ countries, this paper researches the impact of the differences in the energy consumption (ECD) on import dependence in energy trade among B\&R countries, which is a new perspective. Specifically, this paper assumes that the differences in crude oil consumption (OCD) and natural gas consumption (GCD) have a positive impact on import dependence in crude oil trade and natural gas trade among B\&R countries, respectively (Hypothesis 7 and Hypothesis 8).

\section{Data and method}

\subsection{Data}

The energy trade data among B\&R countries are downloaded from the UN Comtrade. The energy commodities include crude oil and natural gas. Their HS codes are 2709 and 271111, respectively. Each data unit includes the exporter, importer, trade type and trade volume.

Based on a literature review, the influencing factors of import dependence in energy trade among B\&R countries selected in this paper are SD, ED, FTA, OCD and GCD. The distance between national capitals is used to represent $\mathrm{SD}$, which is downloaded from the CEPII database. FTA data is downloaded from the website of the World Trade Organization. GDP and population of countries are obtained from the website of the World Bank. Crude oil and natural gas consumption data are downloaded from the Eora global supply chain database (Lenzen et al., 2012, 2013). Because of the lack of data in some countries, 59 countries are selected for empirical study, as shown in Appendix A, Table A1.

Since the energy consumption data in the Eora global supply chain database is only released in 2015, the data period of this study is from 2002 to 2015. Through the analysis of historical data, countries can understand the evolution trend of their energy import dependence among B\&R countries and then adopt energy trade strategies.

\subsection{Network construction}

This study constructs an EIDN among 59 countries, of which the nodes are countries, the edges are energy trade dependence relationships and the direction of the edge is the flow of trade. Thus, the EIDN is directed. The EIDN with network matrix Energy ${ }^{a}$ is defines as Eq. (1): 


$$
\text { Energy }^{a}=\left(V_{\text {countries }}, E_{\text {trade }}\right)=\left[\begin{array}{cccccc}
0 & \cdots & \cdots & E_{1 j}^{a} & \cdots & E_{1 n}^{a} \\
\vdots & \ddots & \ddots & \vdots & \ddots & \vdots \\
E_{i 1}^{a} & \cdots & \cdots & E_{i j}^{a} & \cdots & E_{i n}^{a} \\
\vdots & \ddots & \ddots & \vdots & \ddots & \vdots \\
\vdots & \ddots & \ddots & \vdots & \ddots & \vdots \\
E_{n 1}^{a} & \cdots & \cdots & E_{n j}^{a} & \cdots & 0
\end{array}\right] \text {, }
$$

where $a=$ (crude oil or natural gas). $V_{\text {countries }}$ is the node set, $E_{\text {trade }}$ is the edge set, and $n$ is the number of countries. $E_{i j}^{a}$ represents country $j$ 's import dependence in energy trade of country $i$, defined as Eq. (2):

$$
E_{i j}^{a}=\frac{T V_{i j}^{a}}{T T V_{j}^{a}},
$$

where $T V_{i j}^{a}$ represents the energy $a$ 's trade volume exporting from $i$ to $j . T T V_{j}^{a}$ is the energy $a$ 's total import volume for $j$ from the world. Figure 1 shows the trade dependence network of crude oil and natural gas in 2015. The larger the node, the higher the energy import dependence of the country. The thicker the edge, the higher the energy import dependence between countries.

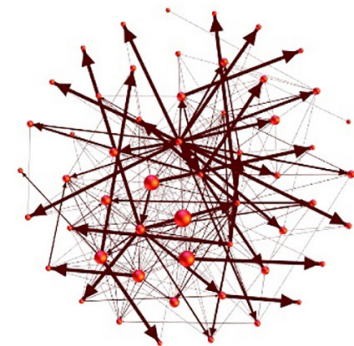

Crude oil

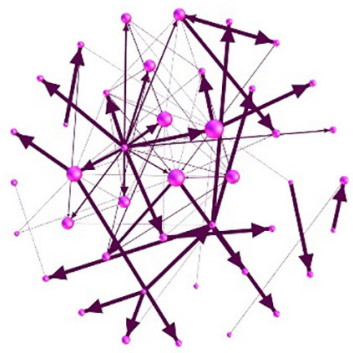

Natural gas

Figure 1. The import dependence network of crude oil and natural gas in 2015

\subsection{Network indices}

\subsubsection{The number of energy importing partners among $B \& R$ countries}

In the EIDN, the in-degree of country $i$ represents the number of countries that country $i$ imports energy from, which is defined as $D_{i n}^{a}(i)$. It describes the number of energy importing partners of $i$. The larger the in-degree of the country, the larger the number of energy importing partners. The average number of energy importing partners among B\&R countries is defined as $A D_{\text {in }}^{a}$.

$$
D_{i n}^{a}(i)=\sum_{j=1}^{n} D_{j i}^{a}
$$




$$
\begin{gathered}
A D_{i n}^{a}=\frac{\sum_{i=1}^{n} \sum_{j=1}^{n} D_{j i}^{a}}{n} ; \\
D_{j i}^{a}=\left\{\begin{array}{l}
1, E_{j i}^{a}>0 \\
0, E_{j i}^{a}=0
\end{array}\right.
\end{gathered}
$$

\subsubsection{Import dependence in energy trade among $B \& R$ countries}

In the EIDN, the weighted in-degree of country $i$ represents the energy import dependence of $i$ on the other $\mathrm{B} \& \mathrm{R}$ countries, defined as $W D_{i n}^{a}(i)$. It ranges from 0 to 1 . The larger the weighted in-degree of the country, the higher its import dependence in energy trade. The average value of import dependence in energy trade among 59 countries is defined as $A W D_{i n}^{a}$.

$$
\begin{gathered}
W D_{i n}^{a}(i)=\sum_{j=1}^{n} E_{j i}^{a} ; \\
A W D_{i n}^{a}=\frac{\sum_{i=1}^{n} \sum_{j=1}^{n} E_{j i}^{a}}{n} .
\end{gathered}
$$

\subsection{QAP regression model}

QAP has been widely used in network analysis and is a useful tool for revealing the correlation and regression relationships among matrices (Cranmer et al., 2017; Xu \& Cheng, 2016). The dependence relationships and influencing factors can be represented as matrices data (or relational data). QAP is a test analysis method and can be used to perform a hypothetical test on "relation to relation" data. Thus, the QAP method is used to test the regression relationships between energy import dependence and its determinants. The process of QAP multivariate regression analysis includes three steps. First, a traditional regression analysis of the dependent variables and independent variables, which are network matrix (relational data), is carried out. Then, the rows of one of the matrices and the corresponding columns are randomly permutated simultaneously, and the test statistics are recalculated. By repeating this calculation process thousands of times, the distribution of the test statistics is obtained. Finally, by comparing the test statistics calculated in the first step with the distribution of test statistics calculated in the second step, this paper makes a judgment based on whether the observed test statistics fall into the rejection domain or the acceptance domain.

The QAP model is shown in Eq. (8), meaning that the dependent variable energy ${ }^{a}$ is the function of independent variables $S D, E D, F T A, E C D$.

$$
\text { energy }^{a}=f(S D, E D, F T A, E C D) .
$$

All the variables are matrix data. energy ${ }^{a}$ is the trade dependence matrix of energy $a$. Matrix SD is the spherical distance between any two national capitals that have trade relationships. If two countries sign an FTA, then the corresponding element of matrix FTA is 
1, otherwise it is 0 . Based on the economic distance index proposed by Chong et al. (2019), matrix ED is defined in Eq. (9), representing the economic difference between exporters and importers. ECD includes matrices OCD and GCD respectively according to the energy $a$, and OCD and GCD represent the difference in crude oil and natural gas consumption between exporters and importers, respectively, defined in Eqs (10)-(11).

$$
\begin{gathered}
E D_{i j}=\frac{\left(P G D P_{i}-P G D P_{j}\right)^{2}}{G D P_{i} \times G D P_{j}} ; \\
O C D_{i j}=\frac{\left(P O i l_{i}-P O i l_{j}\right)^{2}}{O i_{i} \times O i l_{j}} ; \\
G C D_{i j}=\frac{\left(\text { PGas }_{i}-P G a s_{j}\right)^{2}}{\text { Gas }_{i} \times \text { Gas }_{j}},
\end{gathered}
$$

where $i$ and $j$ are the $\mathrm{B} \& \mathrm{R}$ countries, representing the energy exporter and importer, respectively; $G D P_{i}$ represents the GDP of country $i$, and $P G D P_{i}$ represents the per capita GDP of country $i$; Oil $l_{i}$ and $G_{a} s_{i}$ are the crude oil and natural gas consumption of country $i$, respectively; $\mathrm{POil}_{i}$ and $P G a s_{i}$ are the per capita crude oil and natural gas consumption of $i$, respectively. Since the differences between countries are large, each of the matrices is normalized.

\section{Results and discussion}

To better understand the results, this study provides the crude oil and natural gas production, consumption, exports and imports of $B \& R$ countries and calculates the net imports of each country to judge whether the country is a net importing country or not; please see Appendix, Tables A2 and A3.

\subsection{The overall evolution of the energy import dependence pattern}

This study constructs the trade dependence network of crude oil (COTDN) and natural gas (NGTDN) from 2002 to 2015. The numbers of nodes and edges in a network are basic topology features. Analysing the evolution of topology characteristics of networks can help us understand the energy trade pattern among 59 countries from an overall perspective and the extent to which countries are participating in regional energy trade.

Firstly, the number of $\mathrm{B} \& \mathrm{R}$ countries participating in energy trade is analysed. The numbers of countries in the COTDNs fluctuated slightly, ranging from 51 to 58, as shown in Figure 2. The number of countries involved in regional crude oil trade showed a rising trend before 2008 and reached a peak of 58 in 2008, after which the number of countries decreased. As for natural gas trade, the number of countries fluctuated greatly, ranging from 35 to 48 . Besides, there was an upward trend from 2006 to 2010 reaching a peak of 48 in 2010, after which the number showed a decreasing trend. Secondly, there was an upward trend in the 
number of crude oil and natural gas trade relationships among 59 countries from 2002 to 2015, as shown in Figure 3. Countries tended to seek more new trade links to ensure their energy security. This result is similar to Sun et al. (2017) and Yang et al. (2015), showing the increasing trend of global crude oil trade relationships. Besides, the number of relationships and the growth in COTDN were larger than those in NGTDN, and it increased 93 from 172 in 2002 to 265 in 2015. The number of relationships in the NGTDNs was much lower, ranging from 52 to 85 . With the increasingly prominent environmental problems and the increasing awareness of low carbon and environmental protection, the demand for natural gas shows an increasing trend, and natural gas trade among $B \& \mathrm{R}$ countries has great potential.

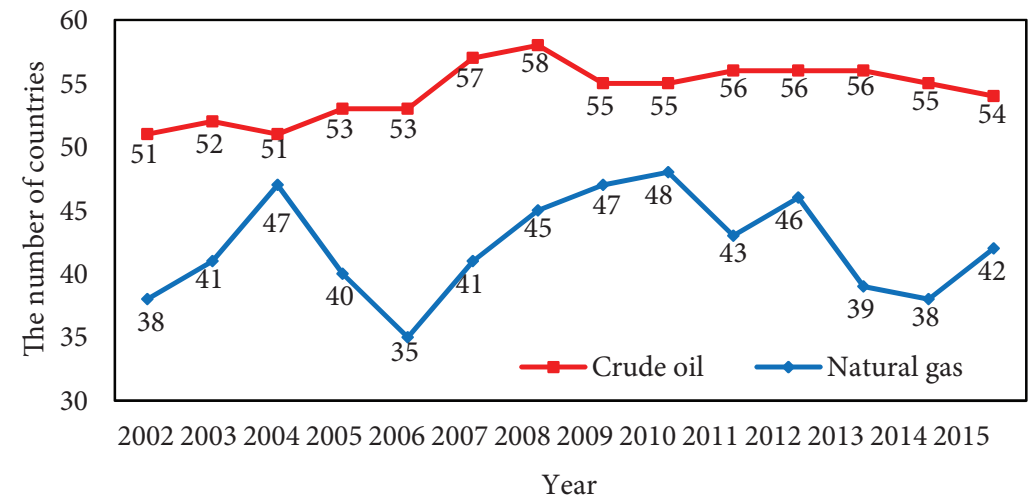

Figure 2. The evolution of the number of B\&R countries in EIDNs

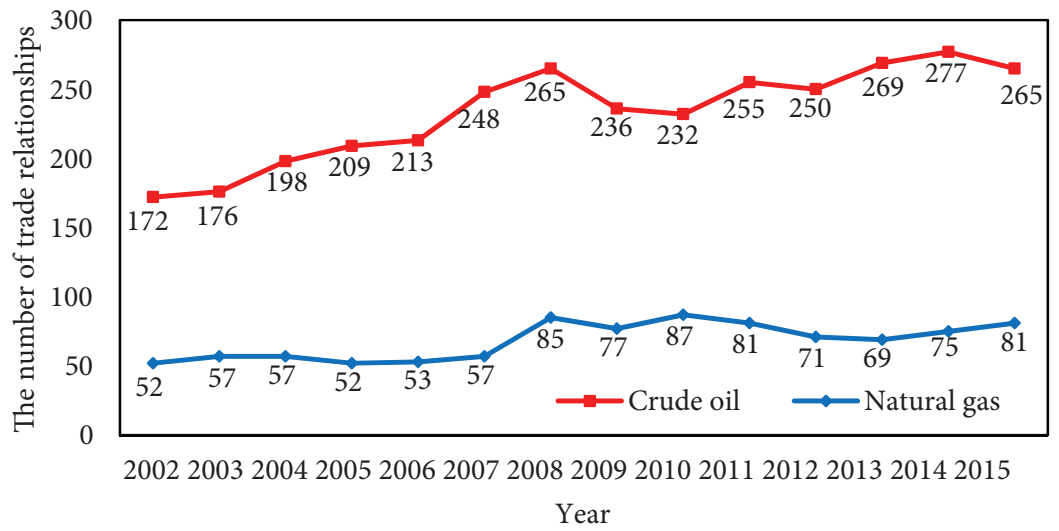

Figure 3. The evolution of the number of trade relationships in EIDNs

\subsection{The number of energy importing partners among $B \& R$ countries}

Through analysing the number of energy importing partners, the number of energy import channels and energy security risk of a country can be revealed. The number of energy importing partners of each country is calculated and the cumulative value in every year is obtained, the distribution of which is shown in Figure 4. In order to identify the evolution 
features, this paper selects the cumulative distribution evolution of the number of energy importing partners in 2002, 2005, 2008, 2011 and 2014 and presents them in the subgraph. Figure 4(a) reveals the cumulative distribution of the number of crude oil importing partners among 59 countries; $20 \%$ of countries accounted for $56 \%$ to $66 \%$ of the trading partners from 2002 to 2015. In 2003, the curve of the cumulative number of crude oil importing partners was the most obvious. Thus, a small number of countries, such as China, India and Singapore, own a large amount of crude oil trade partners. The oil consumption of China and India is relatively large, and oil production cannot satisfy their demands, so they need importing more crude oil from other countries. In order to decrease energy risk, they must expand trade channels and seek more importing partners. Singapore has relatively few resources and needs importing crude oil to support economic development. Besides, Singapore acts as one of the world's major oil trading hubs, so it has lots of crude oil trade partners. From Figure 4(b), 20\% of countries accounted for 53\% of natural gas importing partners in 2002, and $20 \%$ of countries accounted for $72 \%$ of natural gas trading partners in 2015 . Thus, a small number of countries, such as Qatar, Indonesia, Russia, China and Malaysia, own a large amount of natural gas trade partners. In B\&R countries, Qatar, Indonesia, Russia and Malaysia have rich natural gas and are major natural gas exporters, and China is the biggest natural gas importers. In order to ensure the security of energy export and energy consumption, they must build more natural gas partners. The results are in line with Zhong et al. (2016). Besides, some countries were not involved in the natural gas trade among B\&R countries, such as Iraq, Maldives and Serbia.

The average number of energy importing partners among B\&R countries is also calculated, as shown in Figure 5. The average numbers of crude oil and natural gas importing partners fluctuated from 2.9 to 4.7 and from 0.9 to 1.5 , respectively, indicating that the natural gas trade relationships among $B \& R$ countries were not close. $B \& R$ countries are rich in crude oil and natural gas resources, but the distribution is very uneven with the resources mainly concentrated in the Middle East, Central Asia and Russia. However, due to poor infrastructure, the transportation of oil and gas among B\&R countries is largely restricted. With the financial support of the Asian infrastructure investment bank and the Silk Road Fund, the infrastructure construction of transportation, logistics and information communication among
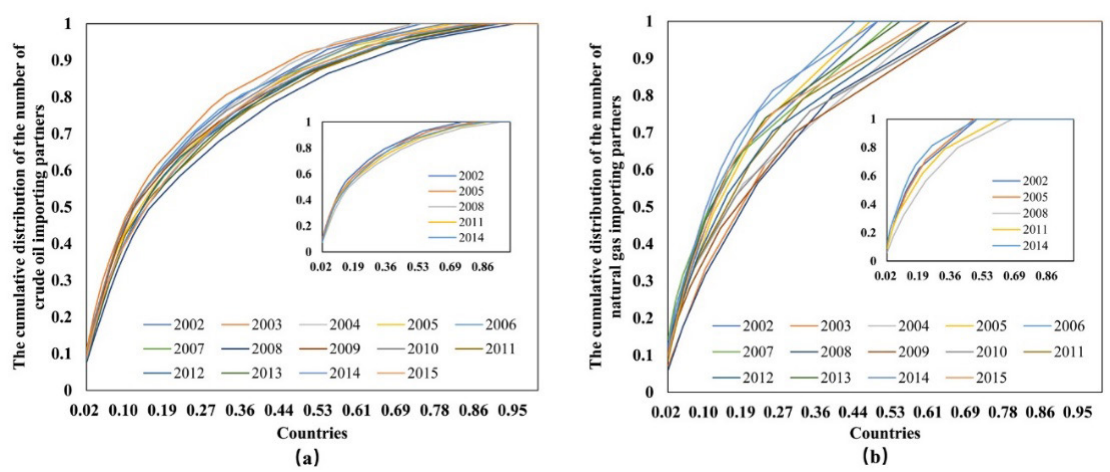

Figure 4. The cumulative distribution map of crude oil and natural gas importing partners among $\mathrm{B} \& \mathrm{R}$ countries 


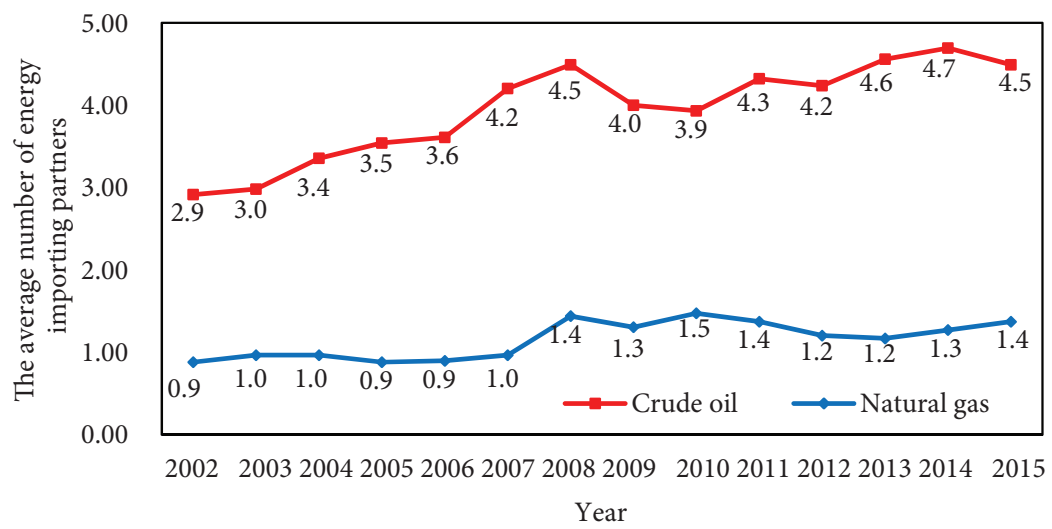

Figure 5. The average number of crude oil and natural gas importing partners among $B \& R$ countries

$B \& R$ countries could be greatly improved, promoting connectivity of oil and gas trade among countries. For China, it is the largest importer of oil and gas and imports a large amount of oil and gas from the Middle East countries by maritime transportation, and the seaborne routes must via the Strait of Malacca. A variety of event, such as piracy, terrorism and emergencies, could easily lead to a short-term disruption of transport across the Strait of Malacca, leading to global or local supply disruptions of oil and gas (Muhammad \& Long, 2020). For Russia, the spatial distance from Russia to other B\&R countries is much shorter, and the crude oil trade from Russia to others are more convenient and safety by pipelines. Besides, land pipeline transportation can ensure all-weather uninterrupted energy transportation, and is not affected by climate and season. Thus, for diversifying energy trade channels among B\&R countries and increase the security of energy transportation, it is necessary to improve the transport capacity of land channels by constructing more crude oil and natural gas pipelines. For example, China could further push the cooperation of pipeline construction with Russia, Kazakhstan, Uzbekistan and Myanmar. Besides, all the B\&R countries should make full use of the development opportunities brought by the Belt and Road Initiative to strengthen cooperation mechanisms and form a pattern of mutual benefit.

\subsection{Import dependence in energy trade among $B \& R$ countries}

Through analysing the import dependence in energy trade, the energy dependence pattern among countries and the degree of the energy dependence of each country on others can be revealed; thus, this paper can provide implications to certain countries.

The import dependence in crude oil and natural gas trade among 59 countries is calculated, the evolution of which is shown in Figure 6. Figure 6(a) shows the distribution of import dependence in crude oil trade among 59 countries over time, which is relatively intensive. The import dependence in crude oil trade of more than 30 countries on other B\&R countries is over 0.9 every year, and the importing partners of some countries are only 1 or 2 , such as Mongolia and Myanmar. This is because the level of industrialization in these countries is relatively low and they do not need more oil to support their economic development. 

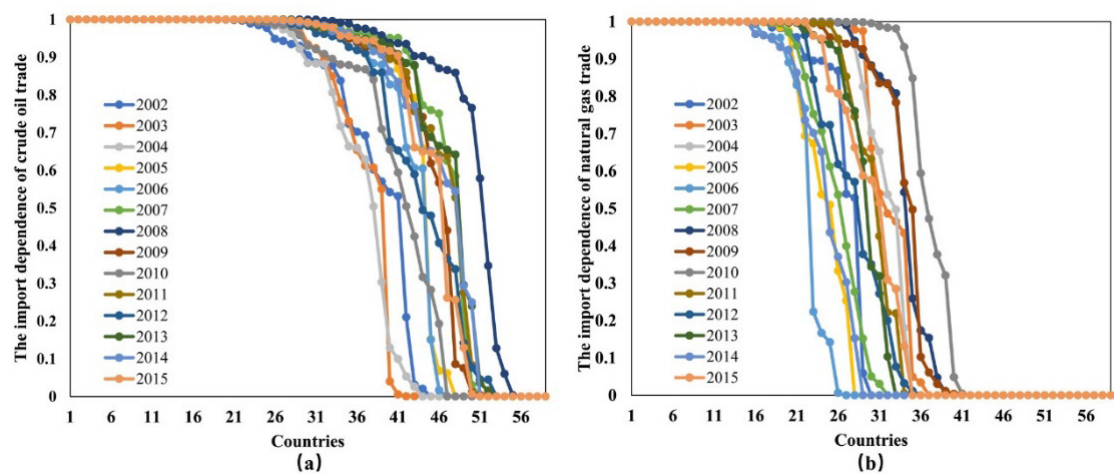

Figure 6. Import dependence in crude oil and natural gas trade among B\&R countries

However, if their exporter cut the oil provides, the economies of these countries will be greatly influenced. Thus, these countries should diversify their trade partners and maintain existing relationships. In 2008, import dependence in crude oil trade was relatively high, and import dependence in crude oil trade of 20 countries on other B\&R countries was 1 , indicating that the crude oil trade relationships and dependence relationships among $B \& R$ countries were denser. Overall, import dependence in crude oil trade among B\&R countries is high with high risk.

The distribution of import dependence in natural gas trade among 59 countries is less intensive compared to crude oil, as shown in Figure 6(b). Specifically, the number of countries for which import dependence in natural gas trade was 1 or 0 is large. These countries totally relied on 1 or $2 \mathrm{~B} \& \mathrm{R}$ countries to provide natural gas. Therefore, these countries had a high natural gas importing risk since if their partner(s) stop exporting natural gas to them, the operation of natural gas-related industries of these countries will be influenced. Besides, there were 24 countries whose import dependence was 0 in 2015. The figure indicates that some B\&R countries had close natural gas relationships with high dependence, while some countries did not have natural gas trade dependence relationships with other $\mathrm{B} \& \mathrm{R}$ countries at all. Gas trade in the Asia-Pacific region is dominated by liquified natural gas, so B\&R countries transport liquified natural gas relying on sea transportation with higher cost and higher risk. Besides, the energy consumption structure of $\mathrm{B} \& \mathrm{R}$ countries is dominated by coal and oil consumption, causing less natural gas trade relationships among these countries.

\subsection{QAP regression analysis}

Through analysing the QAP regression results between influencing factors and import dependence in energy trade, the influence mechanism of the energy import dependence pattern (topological structure) among 59 countries is revealed. This helps to understand the influencing factors hindering or facilitating the energy dependence among B\&R countries, and then countries can take measures to ensure their energy importing security. Based on the QAP method, the regression relationships between import dependence in energy trade and SD, ED, FTA and ECD are obtained. The results are shown in Table 1. 
Firstly, hypotheses 1 and 2 assume that SD hinders the import dependence on crude oil and natural gas trade among $B \& R$ countries. According to the results reported, the SD had a significantly positive impact on crude oil and natural gas import dependence among B\&R countries. This is not in line with Chong et al. (2019), which concluded that SD has a negative impact on the trade relationships among B\&R countries. Energy is the main material of a country's economic development, and a large amount of oil and gas are distributed in B\&R countries, especially in Russia, the Middle East and Central Asia. For crude oil, most net importing countries with a large number of imports and import partners in B\&R countries, such as China, India, Thailand, Singapore and Indonesia, are located in East Asia, South Asia and Southeast Asia. Most net exporting countries with a large number of exports and export partners in B\&R countries, such as Saudi Arabia, Russia, United Arab Emirates, Iraq and Iran, are located in the Middle East and Europe. There are many import dependence relationships between the two kinds of countries. Thus, though the spatial distances between these two kinds of countries are large, but due to the importance of crude oil on economic development, crude oil importing countries must bear the high cost of energy transportation and carry out trade from exporting countries. For natural gas, some net importing countries in B\&R countries have large import volumes and import partners, such as China, Turkey, India and the United Arab Emirates. While some net exporting countries in B\&R countries, such as Russia, Qatar and Malaysia, have large export volumes and export partners. There is a large space distance between these countries, and in order to satisfy the demand for natural gas, countries must bear high transportation costs and carry out trade from exporting countries. In addition, countries in close proximity tend to have similar resource endowments, causing that countries with shorter spatial distance tend not to have crude oil and natural gas import and export relationships, and countries with longer spatial distance are likely to have more trade relationships and high import dependence relationships. Therefore, hypothesis 1 and 2 are not confirmed.

Secondly, hypotheses 3 and 4 contend that ED hinders the import dependence of crude oil and natural gas trade among countries. From Table 1, it can be confirmed that ED had a significantly positive influence on import dependence in crude oil and natural gas trade. The reason for this is that the degree of economic development varies greatly among $B \& R$ countries, and the GDP per capita of 37 B\&R countries was less than $\$ 10000$ in 2015, while the GDP per capita of the United Arab Emirates and Singapore, who have relatively large energy trade relationships, was more than $\$ 35000$ in 2015 . Thus, the ED among B\&R countries is large, and due to the importance of energy commodities, countries must carry out energy trade. Therefore, hypotheses 3 and 4 are not corroborated.

Thirdly, hypotheses 5 and 6 contend that the signing of FTAs has a positive influence on import dependence in crude oil and natural gas trade among countries. As shown in the regression results, except for that the influence of FTA on crude oil import dependence is not significant in 2003, the coefficients of FTA on crude oil and natural gas import dependence are significantly positive in other years. This is in line with Erdey and Postenyi (2017) and Chong et al. (2019). Therefore, hypothesis 5 and 6 are corroborated.

Fourthly, hypotheses 7 and 8 predict that OCD and GCD facilitate the crude oil and natural gas import dependence respectively. According to the results reported in Table 1, the 
regression coefficients of OCD and GCD are significantly positive. Therefore, hypothesis 7 and 8 are confirmed. In addition, this paper calculates the correlation between the ED and ECD every year and adds stepwise regression analysis to prove that there is no multicollinearity between ED and ECD, shown in Appendix, Tables A4 and A5.

Table 1. The regression results of influencing factors on the import dependence in energy trade

\begin{tabular}{|c|c|c|c|c|c|c|c|c|}
\hline \multirow{2}{*}{ Year } & \multicolumn{4}{|c|}{ Crude oil } & \multicolumn{4}{|c|}{ Natural Gas } \\
\hline & SD & ED & FTA & OCD & SD & ED & FTA & GCD \\
\hline 2002 & $0.243^{* * *}$ & $0.063^{\star *}$ & $0.056^{* * *}$ & $0.072^{* * *}$ & $0.604^{* * *}$ & $0.063^{\star *}$ & $0.038^{* * *}$ & $0.037^{\star \star}$ \\
\hline 2003 & $0.249^{* * *}$ & $0.028^{*}$ & 0.025 & $0.082^{* * *}$ & $0.567^{\star * *}$ & $0.092^{* * *}$ & $0.030^{\star *}$ & $0.022^{*}$ \\
\hline 2004 & $0.261^{\star * *}$ & 0.014 & $0.044^{\star *}$ & $0.120^{* * *}$ & $0.275^{\star * *}$ & $0.160^{* * *}$ & $0.084^{\star * *}$ & $0.264^{\star * *}$ \\
\hline 2005 & $0.274^{\star * *}$ & $0.045^{\star *}$ & $0.064^{\star * *}$ & $0.060^{* *}$ & $0.449^{\star * *}$ & $0.134^{\star * *}$ & $0.038^{\star * *}$ & $0.146^{\star * *}$ \\
\hline 2006 & $0.219^{\star * *}$ & $0.092^{* * *}$ & $0.055^{\star * *}$ & $0.115^{\star * *}$ & $0.456^{\star * *}$ & $0.064^{\star *}$ & $0.047^{* * *}$ & $0.126^{\star * *}$ \\
\hline 2007 & $0.203^{\star * *}$ & $0.105^{\star \star *}$ & $0.088^{\star * *}$ & $0.094^{* * *}$ & $0.423^{\star * *}$ & $0.075^{\star * *}$ & $0.079^{* * *}$ & $0.178^{\star * *}$ \\
\hline 2008 & $0.219^{* * *}$ & $0.066^{\star *}$ & $0.072^{\star * *}$ & $0.119^{* * *}$ & $0.492^{* * *}$ & $0.100^{* * *}$ & $0.054^{* * *}$ & $0.078^{\star * \star}$ \\
\hline 2009 & $0.226^{* * *}$ & 0.023 & $0.052^{* * *}$ & $0.182^{\star * *}$ & $0.137^{\star * *}$ & $0.071^{* * *}$ & $0.034^{* * *}$ & $0.528^{* * *}$ \\
\hline 2010 & $0.218^{\star * *}$ & $0.028^{*}$ & $0.048^{\star * *}$ & $0.131^{* * *}$ & $0.213^{\star * *}$ & $0.249^{\star * *}$ & $0.042^{\star * *}$ & $0.422^{\star * *}$ \\
\hline 2011 & $0.223^{\star * *}$ & $0.053^{* *}$ & $0.059^{\star * *}$ & $0.115^{\star * *}$ & $0.346^{* * *}$ & $0.196^{* * *}$ & $0.061^{* * *}$ & $0.149^{* * *}$ \\
\hline 2012 & $0.199^{* * *}$ & $0.091^{* * *}$ & $0.076^{* * *}$ & $0.117^{\star * *}$ & $0.068^{\star * *}$ & $0.245^{\star * *}$ & $0.074^{* * *}$ & $0.430^{\star * *}$ \\
\hline 2013 & $0.185^{\star * *}$ & $0.076^{* *}$ & $0.083^{* * *}$ & $0.109^{\star * *}$ & $0.205^{\star * *}$ & $0.315^{\star * *}$ & $0.060^{\star * *}$ & $0.308^{\star * *}$ \\
\hline 2014 & $0.160^{* * *}$ & $0.197^{\star * *}$ & $0.092^{* * *}$ & $0.089^{* * *}$ & $0.124^{\star * *}$ & $0.292^{\star * *}$ & $0.069^{* * *}$ & $0.264^{\star * *}$ \\
\hline 2015 & $0.223^{\star * *}$ & $0.117^{\star * *}$ & $0.073^{* * *}$ & $0.055^{\star \star}$ & $0.167^{\star * *}$ & $0.247^{\star * *}$ & $0.040^{* * *}$ & $0.317^{\star * *}$ \\
\hline
\end{tabular}

Note: The coefficients in the table are standardized regression coefficients. ${ }^{* *},{ }^{* *},{ }^{\star}$ represent significance at the level of $1 \%, 5 \%, 10 \%$, respectively.

\section{Conclusions}

In this paper, the concept of import dependence is provided, and crude oil and natural gas trade among B\&R countries are taken as empirical objects. By using the network method, an EIDN model among B\&R countries is constructed. The evolution characteristics of the EIDNs and the import dependence in energy trade among $B \& R$ countries are revealed. Then, based on a literature review and the availability of data, this paper chooses SD, FTA, ED and ECD as determinants of import dependence in energy trade among B\&R countries. Finally, based on the QAP method, the regression results of these factors are obtained and analyzed. The followings are the conclusions.

(1) From 2002 to 2015, the number of B\&R countries participating in crude oil trade ranged from 51 to 58 , while the number of $B \& R$ countries involving in natural gas trade fluctuated greatly from 35 to 48 . As for the number of trade relationships among B\&R countries, there was an increasing trend in crude oil and natural gas trade. Most of the B\&R countries had a small number of crude oil and natural gas trade partners, leading to a high risk of oil 
and gas security. Besides, the number of crude oil and natural gas importing partners was increasing. Thus, countries were seeking new trade relationships and diversifying their trade partners to ensure their energy security.

(2) Based on the analysis of import dependence in energy trade, it is concluded that the distribution of import dependence in crude oil and natural gas trades among B\&R countries had different characteristics. The import dependence in crude oil trade of more than 30 countries on other $\mathrm{B} \& \mathrm{R}$ countries was over 0.9 every year. A large proportion of $\mathrm{B} \& \mathrm{R}$ countries did not depend on other countries' natural gas, while there were also a large proportion of B\&R countries whose import dependence was 1 , and the importing partners of these countries were only 1 or 2 . Combining the analysis of the number of importing partners and the value of import dependence, it is revealed that the number of importing partners in the crude oil and natural gas trade among B\&R countries is small, but the import dependence is relatively large, indicating that the risk of energy security is higher.

(3) Based on the QAP regression analysis, because of the particularity of energy commodities, some new results are revealed which are different from previous studies (Chong et al., 2019), this paper finds that spatial distance, economic difference, the signing of FTAs and the difference in the energy consumption have significantly positive impacts on the crude oil and natural gas import dependence among B\&R countries.

Combining the results and the current situation of energy trade in B\&R countries, several policy implications are obtained.

(1) B\&R countries should enhance the relationships with trade partners and avoid being highly dependent on one country's energy, which can reduce energy trade risk. As environmental issues become increasingly prominent, the demand for natural gas has an increasing trend. $B \& R$ countries are rich in natural gas resources, and $B \& R$ countries include the largest natural gas exporting countries and consumption countries. The status of natural gas trade in $\mathrm{B} \& \mathrm{R}$ countries will rise. Thus, the natural gas trade among $\mathrm{B} \& \mathrm{R}$ countries has broad prospects. Countries could break down energy trade barriers by building free trade agreements with other $B \& R$ countries. $B \& R$ countries also should be aware that political relationships play crucial roles in energy trade among countries. However, the geopolitical relationships among $\mathrm{B} \& \mathrm{R}$ countries are complex with high political risks. Energy cooperation is an important project in the Belt and Road Initiative, which is a chance for strengthening and deepening cooperation in the field of energy. Through joining the "One Belt One Road" Energy Partnership, B\&R countries could expand energy trade partners and diversify their trade relationships to achieve a win-win cooperation mechanism. This can promote political trust among countries, further promoting crude oil and natural gas trade and cooperation.

(2) Organization of Petroleum Exporting Countries (OPEC), acting as oil-producing countries, were shocked by unconventional oil and gas from the USA in recent several years, and the market share of OPEC was decreasing, causing that the pricing position of OPEC is greatly threatened. Some OPEC members, such as Saudi Arabia, Qatar and so on, also belong to B\&R countries, and they could exploit the opportunities of the Belt and Road Energy cooperation platform to stable their markets. Besides, under the framework of the Belt and Road Initiative, oil-producing and oil-consumption countries are suggested to explore the 
establishment of a mutually beneficial and new win-win crude oil pricing system to jointly maintain the stability of the crude oil market. In addition, as the most important natural gas production and consumption area in the world, B\&R countries are suggested to explore the establishment of a new regional natural gas pricing mechanism under the framework of the Belt and Road Initiative, promoting the development of regional natural gas trade. This also plays an important role in promoting the formation of a unified natural gas pricing system in the world.

(3) For crude oil and natural gas, the import dependence in crude oil trade among B\&R countries is high with high risk. The transportation of oil and gas among B\&R countries mainly relies on sea transportation, while the safety of oil and gas trade between some countries is greatly influenced when passing through the Strait of Malacca and Strait of Hormuz. Thus, it is necessary to construct an inter-regional oil and gas pipeline network and other infrastructure among $B \& R$ countries for reducing the dependence on sea transport, promoting inter-regional oil and gas trade and declining the risk of energy security. The construction of natural gas pipelines also can stimulate the increase of natural gas trade, improve natural gas supply capacity and enhance the flexibility of market supply chains among countries. The projects of pipeline connection are highly related to geopolitics, and the construction of oil and gas pipelines reflects the energy strategic interests between countries to a certain extent. If the governments, financial institutions, oil and gas companies and engineering enterprises could jointly construct oil and gas pipelines, it is of great significance to form a win-win cooperation mechanism and promote the economic development of $\mathrm{B} \& \mathrm{R}$ countries.

Due to the data limitation, this paper analyzes the evolutionary characteristics of the import dependence between $B \& R$ countries in energy trade and its influencing factors from 2002 to 2015 . Although the data is not the newest, by combining the evolutionary characteristics and the current situation of energy trade in B\&R countries, this paper provides several policy implications to promote crude oil and natural gas trade and decrease the energy risk among B\&R countries. Besides, the concept of import dependence proposed in this paper can also be applied to the research of other trade dependence. Future research will focus on the impacts of the distance of energy resource endowment and political distance on the import dependence of energy trade. The import dependence between countries from the perspective the oil and gas industrial chain is also an interesting topic and will be considered in our future study.

\section{Funding}

This work was supported by the <National Natural Science Foundation of China $>$ under Grant [71991485, 71991481, 71991480, 42001242, 41871202]; <Beijing Natural Science Foundation> under Grant [9202013]; <the Scientific Research Initiation Project for High-level Talents of Hebei University> under Grant [NO. 521000981396]; <the Fund from Key Laboratory of Carrying Capacity Assessment for Resource and Environment, Ministry of Natural Resources> under Grant [CCA2019.01]; <the Fundamental Research Funds for the Central Universities> under Grant [265208247]. 


\section{Author contributions}

Qingru Sun and Xiangyun Gao conceived this study and were responsible for the draft of the article. Jingjian Si and Huiling Zhen and Wenting Liang were responsible for data collection and data analysis. Xian Xi and Siyao Liu were responsible for analyzing data and drawing figures.

\section{Disclosure statement}

The authors declare that we did not have any competing financial, professional, or personal interests from other parties.

\section{References}

Aitken, N. D. (1973). The effect of the EEC and EFTA on European Trade: A temporal cross-section analysis. American Economic Review, 63(5), 881-892. https://ideas.repec.org/a/aea/aecrev/v63y1973i5p881-92.html

Armijo, L. E. (2007). The BRICS countries (Brazil, Russia, India, and China) as analytical category: Mirage or insight? Asian Perspective, 31(4), 7-42. https://doi.org/10.1353/apr.2007.0001

Atici, C., \& Furuya, J. (2008). Regional blocs and agricultural trade flow: The case of ASEAN. Japan Agricultural Research Quarterly, 42(2), 115-121. https://doi.org/10.6090/jarq.42.115

Balassa, B. (1979). The changing pattern of comparative advantage in manufactured goods. The Review of Economics \& Statistics, 61(2), 259-266. https://doi.org/10.2307/1924594

Bigerna, S., Bollino, C. A., \& Galkin, P. (2021). Balancing energy security priorities: Portfolio optimization approach to oil imports. Applied Economics, 53(5), 555-574.

https://doi.org/10.1080/00036846.2020.1808573

Caporale, G. M., Rault, C., Sova, R., \& Sova, A. (2009). On the bilateral trade effects of free trade agreements between the EU-15 and the CEEC-4 countries. Review of World Economics, 145(2), 189-206. https://doi.org/10.1007/s10290-009-0011-8

Chaney, T. (2018). The gravity equation in international trade: An explanation. Journal of Political Economy, 126(1), 150-177. https://doi.org/10.1086/694292

Chong, Z., Qin, C., \& Pan, S. (2019). The evolution of the belt and road trade network and its determinant factors. Emerging Markets Finance and Trade, 55(14), 3166-3177. https://doi.org/10.1080/1540496X.2018.1513836

Cranmer, S. J., Leifeld, P., McClurg, S. D., \& Rolfe, M. (2017). Navigating the range of statistical tools for inferential network analysis. American Journal of Political Science, 61(1), 237-251. https://doi.org/10.1111/ajps.12263

Duarte, R., Pinilla, V., \& Serrano, A. (2018). Factors driving embodied carbon in international trade: A multiregional input-output gravity model. Economic Systems Research, 30(4), 545-566. https://doi.org/10.1080/09535314.2018.1450226

Erdey, L., \& Postenyi, A. (2017). Determinants of the exports of Hungary: Trade theory and the gravity model. Acta Oeconomica, 67(1), 77-97. https://doi.org/10.1556/032.2017.67.1.5

Fagiolo, G., Reyes, J., \& Schiavo, S. (2010). The evolution of the world trade web: A weighted-network analysis. Journal of Evolutionary Economics, 20(4), 479-514.

https://doi.org/10.1007/s00191-009-0160-x 
Feng, L. Y., Xu, H. L., Wu, G., Zhao, Y., \& Xu, J. L. (2020). Exploring the structure and influence factors of trade competitive advantage network along the Belt and Road. Physica A: Statistical Mechanics and Its Applications, 559, 125057. https://doi.org/10.1016/j.physa.2020.125057

Geng, J. B., Ji, Q., \& Fan, Y. (2014). A dynamic analysis on global natural gas trade network. Applied Energy, 132, 23-33. https://doi.org/10.1016/j.apenergy.2014.06.064

Ho, D. C. K., Chan, E. M. H., Yip, T. L., \& Tsang, C. W. (2020). The United States' clothing imports from Asian countries along the Belt and Road: An extended gravity trade model with application of artificial neural network. Sustainability, 12(18), 7433. https://doi.org/10.3390/su12187433

Kandogan, Y. (2003). Intra-industry trade of transition countries: Trends and determinants. Emerging Market Review, 4(3), 273-286. https://doi.org/10.1016/S1566-0141(03)00040-2

Kitamura, T., \& Managi, S. (2017). Driving force and resistance: Network feature in oil trade. Applied Energy, 208, 361-375. https://doi.org/10.1016/j.apenergy.2017.10.028

Krugman, P. R. (1987). Is free trade passe? Journal of Economic Perspectives, 1(2), 131-144. https://doi.org/10.1257/jep.1.2.131

Liang, X. D., Yang, X., Yan, F. H., \& Li, Z. (2020). Exploring global embodied metal flows in international trade based combination of multi-regional input-output analysis and complex network analysis. Resources Policy, 67, 101661. https://doi.org/10.1016/j.resourpol.2020.101661

Lenzen, M., Kanemoto, K., Moran, D., \& Geschke, A. (2012). Mapping the structure of the world economy. Environmental Science \& Technology, 46(15), 8374-8381. https://doi.org/10.1021/es300171x

Lenzen, M., Moran, D., Kanemoto, K., \& Geschke, A. (2013). Building Eora: A global multi-region input-output database at high country and sector resolution. Economic Systems Research, 25(1), 20-49. https://doi.org/10.1080/09535314.2013.769938

Li, J. P., Sun, X. L., Wang, F., \& Wu, D. S. (2015). Risk integration and optimization of oil-importing maritime system: A multi-objective programming approach. Annals of Operations Research, 234(1), 57-76. https://doi.org/10.1007/s10479-014-1550-5

Muhammad, S., \& Long, X. L. (2020). China's seaborne oil import and shipping emissions: The prospect of belt and road initiative. Marine Pollution Bulletin, 158, 111422. https://doi.org/10.1016/j.marpolbul.2020.111422

Matthee, M., \& Santana-Gallego, M. (2017). Identifying the determinants of South Africa's extensive and intensive trade margins: A gravity model approach. South African Journal of Economic and Management Sciences, 20(1), 1-13. https://doi.org/10.4102/sajems.v20i1.1554

Petreski, M. (2013). Southeastern European trade analysis: A role for endogenous CEFTA-2006? Emerging Markets Finance \& Trade, 49(5), 26-44. https://doi.org/10.2753/REE1540-496X490502

Santana-Gallego, M., Ledesma-Rodriguez, F. J., \& Perez-Rodriguez, J. V. (2016). International trade and tourism flows: An extension of the gravity model. Economic Modelling, 52, 1026-1033. https://doi.org/10.1016/j.econmod.2015.10.043

Shuai, J., Leng, Z. H., Cheng, J. H., \& Shi, Z. Y. (2020). China's renewable energy trade potential in the "Belt-and-Road" countries: A gravity model analysis. Renewable Energy, 161, 1025-1035. https://doi.org/10.1016/j.renene.2020.06.134

Spring, E., \& Grossmann, V. (2016). Does bilateral trust across countries really affect international trade and factor mobility? Empirical Economics, 50, 103-136. https://doi.org/10.1007/s00181-015-0915-1

Sun, Q. R., Gao, X. Y., Zhong, W. Q., \& Liu, N. R. (2017). The stability of the international oil trade network from short-term and long-term perspectives. Physica a-Statistical Mechanics and Its Applications, 482, 345-356. https://doi.org/10.1016/j.physa.2017.04.047

Sun, X. L., Liu, C., Chen, X. W., \& Li, J. P. (2017). Modeling systemic risk of crude oil imports: Case of China's global oil supply chain. Energy, 121, 449-465. https://doi.org/10.1016/j.energy.2017.01.018 
Vivoda, V. (2019). LNG import diversification and energy security in Asia. Energy Policy, 129, 967-974. https://doi.org/10.1016/j.enpol.2019.01.073

Wang, J., Sun, X. L., Li, J. P., Chen, J. M., \& Liu, C. (2018). Has China's oil-import portfolio been optimized from 2005 to 2014? A perspective of cost-risk tradeoff. Computers \& Industrial Engineering, 126, 451-464. https://doi.org/10.1016/j.cie.2018.10.005

Wang, M., \& Kong, R. (2019). Study on the characteristics of potassium salt international trade based on complex network. Journal of Business Economics and Management, 20(5), 1000-1021. https://doi.org/10.3846/jbem.2019.10455

Wu, Z. N., Cai, H. B., Zhao, R. N., Fan, Y., Di, Z. R., \& Zhang, J. (2020). A topological analysis of trade distance: Evidence from the gravity model and complex flow networks. Sustainability, 12(9), 3511. https://doi.org/10.3390/su12093511

Xie, M. J. (2018). Can cultural affinity promote trade? HSK test data from the belt and road countries. China \& World Economy, 26(3), 109-126. https://doi.org/10.1111/cwe.12245

$\mathrm{Xu}, \mathrm{H}$. L., \& Cheng, L. (2016). The QAP weighted network analysis method and its application in international services trade. Physica A: Statistical Mechanics and Its Applications, 448, 91-101. https://doi.org/10.1016/j.physa.2015.12.094

Yang, Y., Poon, J. P. H., Liu, Y., \& Bagchi-Sen, S. (2015). Small and flat worlds: A complex network analysis of international trade in crude oil. Energy, 93, 534-543. https://doi.org/10.1016/j.energy.2015.09.079

Zhang, H. W., Wang, Y., Yang, C., \& Guo, Y. Q. (2021). The impact of country risk on energy trade patterns based on complex network and panel regression analyses. Energy, 222, 119979. https://doi.org/10.1016/j.energy.2021.119979

Zhang, H. Y., Xi, W. W., Ji, Q., \& Zhang, Q. (2018). Exploring the driving factors of global LNG trade flows using gravity modelling. Journal of Cleaner Production, 172, 508-515. https://doi.org/10.1016/j.jclepro.2017.10.244

Zhong, W. Q., An, H. Z., Fang, W., Gao, X. Y., \& Dong, D. (2016). Features and evolution of international fossil fuel trade network based on value of emergy. Applied Energy, 165, 868-877. https://doi.org/10.1016/j.apenergy.2015.12.083

Zhong, W. Q., An, H. Z., Shen, L., Fang, W., Gao, X. Y., \& Dong, D. (2017). The roles of countries in the international fossil fuel trade: An emergy and network analysis. Energy Policy, 100, 365-376. https://doi.org/10.1016/j.enpol.2016.07.025 


\section{APPENDIX}

Table A1. Countries selected in this research

\begin{tabular}{|c|l|l|l|l|l|}
\hline & \multicolumn{1}{|c|}{ Country } & & \multicolumn{1}{|c|}{ Country } & & \multicolumn{1}{c|}{ Country } \\
\hline 1 & Afghanistan & 21 & Indonesia & 41 & Pakistan \\
\hline 2 & Albania & 22 & Iran, Islamic Rep. & 42 & Philippines \\
\hline 3 & Armenia & 23 & Iraq & 43 & Poland \\
\hline 4 & Azerbaijan & 24 & Israel & 44 & Qatar \\
\hline 5 & Bahrain & 25 & Jordan & 45 & Romania \\
\hline 6 & Bangladesh & 26 & Kazakhstan & 46 & Russian Federation \\
\hline 7 & Belarus & 27 & Kuwait & 47 & Saudi Arabia \\
\hline 8 & Bhutan & 28 & Kyrgyz Republic & 48 & Serbia \\
\hline 9 & Bosnia and Herzegovina & 29 & Lao PDR & 49 & Singapore \\
\hline 10 & Brunei Darussalam & 30 & Latvia & 50 & Slovak Republic \\
\hline 11 & Bulgaria & 31 & Lebanon & 51 & Slovenia \\
\hline 12 & Cambodia & 32 & Lithuania & 52 & Sri Lanka \\
\hline 13 & China & 33 & Macedonia, FYR & 53 & Tajikistan \\
\hline 14 & Croatia & 34 & Malaysia & 54 & Thailand \\
\hline 15 & Czech Republic & 35 & Maldives & 55 & Turkey \\
\hline 16 & Egypt, Arab Rep. & 36 & Moldova & 56 & Ukraine \\
\hline 17 & Estonia & 37 & Mongolia & 57 & United Arab Emirates \\
\hline 18 & Georgia & 38 & Myanmar & 58 & Vietnam \\
\hline 19 & Hungary & 39 & Nepal & 59 & Yemen, Rep. \\
\hline 20 & India & 40 & Oman & & \\
\hline & & & \\
\hline
\end{tabular}

Table A2. The crude oil production, consumption, exports and imports of B\&R countries

\begin{tabular}{|l|c|c|c|c|c|c|}
\hline \multicolumn{1}{|c|}{ Country } & $\begin{array}{c}\text { Produc- } \\
\text { tion } \\
\text { (in 2018) }\end{array}$ & $\begin{array}{c}\text { Refined petroleum } \\
\text { products con- } \\
\text { sumption (in } \\
2016 \text { ) }\end{array}$ & $\begin{array}{c}\text { Exports } \\
\text { (in 2018) }\end{array}$ & $\begin{array}{c}\text { Imports } \\
\text { (in 2018) }\end{array}$ & $\begin{array}{c}\text { Net } \\
\text { imports } \\
\text { (in 2018) }\end{array}$ & $\begin{array}{c}\text { Net } \\
\text { importing } \\
\text { country } \\
\text { (in 2018) }\end{array}$ \\
\hline Afghanistan & 0 & $1.28 \times 10^{7}$ & 0 & $1.35 \times 10^{6}$ & $1.35 \times 10^{6}$ & Yes \\
\hline Albania & $5.11 \times 10^{6}$ & $1.06 \times 10^{7}$ & $4.24 \times 10^{6}$ & 0 & $-4.24 \times 10^{6}$ & No \\
\hline Armenia & 0 & $2.92 \times 10^{6}$ & 0 & 0 & 0 & - \\
\hline Azerbaijan & $2.91 \times 10^{8}$ & $3.65 \times 10^{7}$ & $2.72 \times 10^{8}$ & $9.64 \times 10^{5}$ & $-2.71 \times 10^{8}$ & No \\
\hline Bahrain & $1.46 \times 10^{7}$ & $2.23 \times 10^{7}$ & $7.92 \times 10^{6}$ & $7.93 \times 10^{7}$ & $7.14 \times 10^{7}$ & Yes \\
\hline Bangladesh & $1.10 \times 10^{6}$ & $3.87 \times 10^{7}$ & 0 & $1.74 \times 10^{2}$ & $1.74 \times 10^{2}$ & Yes \\
\hline Belarus & $1.13 \times 10^{7}$ & $5.15 \times 10^{7}$ & $1.20 \times 10^{7}$ & $1.33 \times 10^{8}$ & $1.21 \times 10^{8}$ & Yes \\
\hline
\end{tabular}


Continued Table A2

\begin{tabular}{|c|c|c|c|c|c|c|}
\hline Country & $\begin{array}{l}\text { Produc- } \\
\text { tion } \\
\text { (in 2018) }\end{array}$ & $\begin{array}{l}\text { Refined petroleum } \\
\text { products con- } \\
\text { sumption (in } \\
2016)\end{array}$ & $\begin{array}{l}\text { Exports } \\
\text { (in 2018) }\end{array}$ & $\begin{array}{l}\text { Imports } \\
\text { (in 2018) }\end{array}$ & $\begin{array}{c}\text { Net } \\
\text { imports } \\
\text { (in 2018) }\end{array}$ & $\begin{array}{l}\text { Net } \\
\text { importing } \\
\text { country } \\
\text { (in 2018) }\end{array}$ \\
\hline Bhutan & 0 & $1.10 \times 10^{6}$ & 0 & 0 & 0 & - \\
\hline $\begin{array}{l}\text { Bosnia and } \\
\text { Herzegovina }\end{array}$ & 0 & $1.17 \times 10^{7}$ & 0 & $4.87 \times 10^{6}$ & $4.87 \times 10^{6}$ & Yes \\
\hline $\begin{array}{l}\text { Brunei } \\
\text { Darussalam }\end{array}$ & $3.65 \times 10^{7}$ & $6.57 \times 10^{6}$ & $4.16 \times 10^{7}$ & $4.72 \times 10^{4}$ & $-4.15 \times 10^{7}$ & No \\
\hline Bulgaria & $3.65 \times 10^{5}$ & $3.54 \times 10^{7}$ & $4.72 \times 10^{3}$ & $4.51 \times 10^{7}$ & $4.51 \times 10^{7}$ & Yes \\
\hline Cambodia & 0 & $1.64 \times 10^{7}$ & 0 & 0 & 0 & - \\
\hline China & $1.38 \times 10^{9}$ & $4.55 \times 10^{9}$ & $1.95 \times 10^{7}$ & $3.41 \times 10^{9}$ & $3.39 \times 10^{9}$ & Yes \\
\hline Croatia & $5.11 \times 10^{6}$ & $2.66 \times 10^{7}$ & $3.13 \times 10^{2}$ & $3.98 \times 10^{7}$ & $3.98 \times 10^{7}$ & Yes \\
\hline $\begin{array}{l}\text { Czech } \\
\text { Republic }\end{array}$ & $7.30 \times 10^{5}$ & $7.80 \times 10^{7}$ (in 2017$)$ & $1.63 \times 10^{5}$ & $5.44 \times 10^{7}$ & $5.42 \times 10^{7}$ & Yes \\
\hline $\begin{array}{l}\text { Egypt, Arab } \\
\text { Rep. }\end{array}$ & $2.33 \times 10^{8}$ & $3.20 \times 10^{8}$ & $8.40 \times 10^{7}$ & $5.18 \times 10^{7}$ & $3.23 \times 10^{7}$ & No \\
\hline Estonia & 0 & $1.03 \times 10^{7}$ (in 2017) & $2.23 \times 10^{4}$ & $3.49 \times 10^{5}$ & $3.26 \times 10^{5}$ & Yes \\
\hline Georgia & $1.46 \times 10^{5}$ & $9.86 \times 10^{6}$ & $6.45 \times 10^{5}$ & $1.49 \times 10^{4}$ & $-6.31 \times 10^{5}$ & No \\
\hline Hungary & $5.84 \times 10^{6}$ & $6.12 \times 10^{7}($ in 2017$)$ & $1.41 \times 10^{6}$ & $4.59 \times 10^{7}$ & $4.45 \times 10^{7}$ & Yes \\
\hline India & $2.59 \times 10^{8}$ & $1.65 \times 10^{9}$ & $4.10 \times 10^{6}$ & $1.77 \times 10^{9}$ & $1.77 \times 10^{9}$ & Yes \\
\hline Indonesia & $2.82 \times 10^{8}$ & $5.84 \times 10^{8}$ & $9.23 \times 10^{7}$ & $1.24 \times 10^{8}$ & $3.17 \times 10^{7}$ & Yes \\
\hline $\begin{array}{l}\text { Iran, Islamic } \\
\text { Rep. }\end{array}$ & $1.55 \times 10^{9}$ & $6.58 \times 10^{8}$ & $1.36 \times 10^{9}$ & $2.8 \times 10^{-2}$ & $-1.35 \times 10^{9}$ & No \\
\hline Iraq & $1.68 \times 10^{9}$ & $3.01 \times 10^{8}$ & $1.41 \times 10^{9}$ & $3.17 \times 10^{4}$ & $-1.41 \times 10^{9}$ & No \\
\hline Israel & $1.42 \times 10^{5}$ & $8.84 \times 10^{7}$ (in 2017 ) & $4.34 \times 10^{4}$ & $9.05 \times 10^{7}$ & $9.05 \times 10^{7}$ & Yes \\
\hline Jordan & $8.03 \times 10^{3}$ & $5.07 \times 10^{7}$ & 0 & $1.72 \times 10^{7}$ & $1.72 \times 10^{7}$ & Yes \\
\hline Kazakhstan & $6.77 \times 10^{8}$ & $1.00 \times 10^{8}$ & $6.56 \times 10^{8}$ & $1.87 \times 10^{5}$ & $-6.56 \times 10^{8}$ & No \\
\hline Kuwait & $1.02 \times 10^{9}$ & $1.63 \times 10^{8}$ & $7.86 \times 10^{8}$ & $8.92 \times 10^{1}$ & $-7.86 \times 10^{8}$ & No \\
\hline $\begin{array}{l}\text { Kyrgyz } \\
\text { Republic }\end{array}$ & $3.65 \times 10^{5}$ & $1.35 \times 10^{7}$ & $5.18 \times 10^{5}$ & $1.85 \times 10^{4}$ & $-4.99 \times 10^{5}$ & No \\
\hline Lao PDR & 0 & $6.57 \times 10^{6}$ & 0 & $4.02 \times 10^{4}$ & $4.02 \times 10^{4}$ & Yes \\
\hline Latvia & 0 & $1.63 \times 10^{7}$ (in 2017) & $4.96 \times 10^{5}$ & $7.43 \times 10^{5}$ & $2.47 \times 10^{5}$ & Yes \\
\hline Lebanon & 0 & $5.62 \times 10^{7}$ & $1.43 \times 10^{5}$ & $6.23 \times 10^{1}$ & $-1.43 \times 10^{5}$ & No \\
\hline Lithuania & $7.3 \times 10^{5}$ & $2.12 \times 10^{7}$ & $3.66 \times 10^{5}$ & $7.06 \times 10^{7}$ & $7.02 \times 10^{7}$ & Yes \\
\hline $\begin{array}{l}\text { Macedonia, } \\
\text { FYR }\end{array}$ & 0 & $7.67 \times 10^{6}$ & 0 & 0 & 0 & - \\
\hline
\end{tabular}


End of Table A2

\begin{tabular}{|c|c|c|c|c|c|c|}
\hline Country & $\begin{array}{l}\text { Produc- } \\
\text { tion } \\
\text { (in 2018) }\end{array}$ & $\begin{array}{l}\text { Refined petroleum } \\
\text { products con- } \\
\text { sumption (in } \\
2016)\end{array}$ & $\begin{array}{l}\text { Exports } \\
\text { (in 2018) }\end{array}$ & $\begin{array}{l}\text { Imports } \\
\text { (in 2018) }\end{array}$ & $\begin{array}{c}\text { Net } \\
\text { imports } \\
\text { (in 2018) }\end{array}$ & $\begin{array}{l}\text { Net } \\
\text { importing } \\
\text { country } \\
\text { (in 2018) }\end{array}$ \\
\hline Malaysia & $2.36 \times 10^{8}$ & $2.57 \times 10^{8}$ & $2.16 \times 10^{8}$ & $1.09 \times 10^{8}$ & $-1.07 \times 10^{8}$ & No \\
\hline Maldives & 0 & $4.02 \times 10^{6}$ & 0 & $1.39 \times 10^{1}$ & $1.39 \times 10^{1}$ & Yes \\
\hline Moldova & 0 & $6.57 \times 10^{6}$ & 0 & 0 & 0 & - \\
\hline Mongolia & $7.3 \times 10^{6}$ & $9.86 \times 10^{6}$ & $6.13 \times 10^{6}$ & $4.35 \times 10^{2}$ & $-6.12 \times 10^{6}$ & No \\
\hline Myanmar & $4.02 \times 10^{6}$ & $4.49 \times 10^{7}$ & $1.45 \times 10^{6}$ & $5.36 \times 10^{6}$ & $3.91 \times 10^{6}$ & Yes \\
\hline Nepal & 0 & $9.86 \times 10^{6}$ & 0 & 0 & 0 & - \\
\hline Oman & $3.57 \times 10^{8}$ & $6.86 \times 10^{7}$ & $6.16 \times 10^{8}$ & $4.19 \times 10^{3}$ & $-6.16 \times 10^{8}$ & No \\
\hline Pakistan & $3.29 \times 10^{7}$ & $2.03 \times 10^{8}$ & $3.68 \times 10^{6}$ & $7.23 \times 10^{7}$ & $6.86 \times 10^{7}$ & Yes \\
\hline Philippines & $4.75 \times 10^{6}$ & $1.55 \times 10^{8}$ & $6.24 \times 10^{6}$ & $9.84 \times 10^{7}$ & $9.21 \times 10^{7}$ & Yes \\
\hline Poland & $7.67 \times 10^{6}$ & $2.37 \times 10^{8}$ (in 2017$)$ & $2.18 \times 10^{6}$ & $2.10 \times 0^{8}$ & $2.08 \times 10^{8}$ & Yes \\
\hline Qatar & $5.34 \times 10^{8}$ & $1.01 \times 10^{8}$ & $2.84 \times 10^{8}$ & $6.62 \times 10^{3}$ & $-2.83 \times 10^{8}$ & No \\
\hline Romania & $2.56 \times 10^{7}$ & $7.23 \times 10^{7}$ & $1.21 \times 10^{5}$ & $6.03 \times 10^{7}$ & $6.02 \times 10^{7}$ & Yes \\
\hline $\begin{array}{l}\text { Russian } \\
\text { Federation }\end{array}$ & $3.93 \times 10^{9}$ & $1.33 \times 10^{9}$ & $2.25 \times 10^{9}$ & $3.64 \times 10^{6}$ & $-2.24 \times 10^{9}$ & No \\
\hline Saudi Arabia & $3.81 \times 10^{9}$ & $1.20 \times 10^{9}$ & $2.62 \times 10^{9}$ & $3.10 \times 10^{4}$ & $-2.62 \times 10^{9}$ & No \\
\hline Serbia & $6.21 \times 10^{6}$ & $2.70 \times 10^{7}$ & $4.21 \times 10^{3}$ & $1.95 \times 10^{7}$ & $1.95 \times 10^{7}$ & Yes \\
\hline Singapore & 0 & $4.83 \times 10^{8}$ & $4.14 \times 10^{6}$ & $5.19 \times 10^{8}$ & $5.14 \times 10^{8}$ & Yes \\
\hline $\begin{array}{l}\text { Slovak } \\
\text { Republic }\end{array}$ & $7.30 \times 10^{4}$ & $3.13 \times 10^{7}$ (in 2017) & $5.52 \times 10^{3}$ & $4.12 \times 10^{7}$ & $4.12 \times 10^{7}$ & Yes \\
\hline Slovenia & $1.83 \times 10^{3}$ & $1.90 \times 10^{7}$ (in 2017) & $5.52 \times 10^{3}$ & $2.18 \times 10^{5}$ & $2.13 \times 10^{5}$ & Yes \\
\hline Sri Lanka & 0 & $4.23 \times 10^{7}$ & $1.46 \times 10^{6}$ & $7 \times 10^{-2}$ & $6 \times 10^{-2}$ & Yes \\
\hline Tajikistan & $6.57 \times 10^{4}$ & $8.76 \times 10^{6}$ & 0 & $1.60 \times 10^{5}$ & $1.60 \times 10^{5}$ & Yes \\
\hline Thailand & $8.32 \times 10^{7}$ & $4.84 \times 10^{8}$ & $1.23 \times 10^{7}$ & $4.26 \times 10^{8}$ & $4.13 \times 10^{8}$ & Yes \\
\hline Turkey & $2.01 \times 10^{7}$ & $3.61 \times 10^{8}$ (in 2017) & $5.44 \times 10^{7}$ & $4.76 \times 10^{7}$ & $-6.89 \times 10^{6}$ & No \\
\hline Ukraine & $1.17 \times 10^{7}$ & $8.50 \times 10^{7}$ & $1.86 \times 10^{3}$ & $1.18 \times 10^{7}$ & $1.18 \times 10^{7}$ & Yes \\
\hline $\begin{array}{l}\text { United Arab } \\
\text { Emirates }\end{array}$ & $1.17 \times 10^{9}$ & $3.27 \times 10^{8}$ & $2.01 \times 10^{9}$ & $4.74 \times 10^{7}$ & $-1.96 \times 10^{9}$ & No \\
\hline Vietnam & $8.83 \times 10^{7}$ & $1.60 \times 10^{8}$ & $3.44 \times 10^{7}$ & $4.04 \times 10^{7}$ & $6.03 \times 10^{6}$ & Yes \\
\hline Yemen, Rep. & $2.23 \times 10^{7}$ & $3.80 \times 10^{7}$ & $1.27 \times 10^{7}$ & $1.28 \times 10^{3}$ & $-1.27 \times 10^{7}$ & No \\
\hline
\end{tabular}

Note: The data of crude oil production and refined petroleum products consumption were downloaded from the Central Intelligence Agency (https://www.cia.gov/). The data of crude oil export and import were downloaded from the UN comtrade (https://comtrade.un.org/). Due to the availability and integrity of the data, the refined petroleum products consumption of most B\&R countries was in 2016, and the crude oil production, export and import data were in 2018. 
Table A3. The natural gas production, consumption, exports and imports of B\&R countries

\begin{tabular}{|c|c|c|c|c|c|c|}
\hline Country & $\begin{array}{l}\text { Production } \\
\text { (in 2017) }\end{array}$ & $\begin{array}{l}\text { Consumption } \\
\quad \text { (in 2017) }\end{array}$ & $\begin{array}{l}\text { Exports } \\
\text { (in 2017) }\end{array}$ & $\begin{array}{l}\text { Imports } \\
\text { (in 2017) }\end{array}$ & $\begin{array}{l}\text { Net imports } \\
\text { (in 2017) }\end{array}$ & $\begin{array}{c}\text { Net } \\
\text { importing } \\
\text { country } \\
\text { (in 2017) }\end{array}$ \\
\hline Afghanistan & $1.64 \times 10^{8}$ & $1.64 \times 10^{8}$ & 0 & 0 & 0 & - \\
\hline Albania & $5.1 \times 10^{7}$ & $5.1 \times 10^{7}$ & 0 & 0 & 0 & - \\
\hline Armenia & 0 & $2.35 \times 10^{9}$ & $2.35 \times 10^{9}$ & 0 & $2.35 \times 10^{9}$ & Yes \\
\hline Azerbaijan & $1.7 \times 10^{10}$ & $1.03 \times 10^{10}$ & $2.10 \times 10^{9}$ & $8.04 \times 10^{9}$ & $-5.95 \times 10^{9}$ & No \\
\hline Bahrain & $1.59 \times 10^{10}$ & $1.59 \times 10^{10}$ & 0 & 0 & 0 & - \\
\hline Bangladesh & $2.95 \times 10^{10}$ & $2.95 \times 10^{10}$ & 0 & 0 & 0 & - \\
\hline Belarus & $5.95 \times 10^{7}$ & $1.77 \times 10^{10}$ & $1.75 \times 10^{10}$ & 0 & $1.75 \times 10^{10}$ & Yes \\
\hline Bhutan & 0 & 0 & 0 & 0 & 0 & - \\
\hline $\begin{array}{l}\text { Bosnia and } \\
\text { Herzegovina }\end{array}$ & 0 & $2.27 \times 10^{8}$ & $2.27 \times 10^{8}$ & 0 & $2.27 \times 10^{8}$ & Yes \\
\hline $\begin{array}{l}\text { Brunei } \\
\text { Darussalam }\end{array}$ & $1.27 \times 10^{10}$ & $3.94 \times 10^{9}$ & 0 & $8.27 \times 10^{9}$ & $-8.27 \times 10^{9}$ & No \\
\hline Bulgaria & $7.93 \times 10^{7}$ & $3.31 \times 10^{9}$ & $3.26 \times 10^{9}$ & $3.12 \times 10^{7}$ & $3.22 \times 10^{9}$ & Yes \\
\hline Cambodia & 0 & 0 & 0 & 0 & 0 & - \\
\hline China & $1.46 \times 10^{11}$ & $2.39 \times 10^{11}$ & $9.76 \times 10^{10}$ & $3.37 \times 10^{9}$ & $9.43 \times 10^{10}$ & Yes \\
\hline Croatia & $1.05 \times 10^{9}$ & $2.58 \times 10^{9}$ & $1.84 \times 10^{9}$ & $1.73 \times 10^{8}$ & $1.67 \times 10^{9}$ & Yes \\
\hline $\begin{array}{l}\text { Czech } \\
\text { Republic }\end{array}$ & $2.29 \times 10^{8}$ & $8.72 \times 10^{9}$ & $8.89 \times 10^{9}$ & 0 & $8.89 \times 10^{9}$ & Yes \\
\hline $\begin{array}{l}\text { Egypt, Arab } \\
\text { Rep. }\end{array}$ & $5.09 \times 10^{10}$ & $5.77 \times 10^{10}$ & $7.08 \times 10^{9}$ & $2.12 \times 10^{8}$ & $6.87 \times 10^{9}$ & Yes \\
\hline Estonia & 0 & $4.81 \times 10^{8}$ & $4.81 \times 10^{8}$ & 0 & $4.81 \times 10^{8}$ & Yes \\
\hline Georgia & $7.36 \times 10^{6}$ & $2.29 \times 10^{9}$ & $2.29 \times 10^{9}$ & 0 & $2.29 \times 10^{9}$ & Yes \\
\hline Hungary & $1.81 \times 10^{9}$ & $1.04 \times 10^{10}$ & $1.34 \times 10^{10}$ & $3.52 \times 10^{9}$ & $9.85 \times 10^{9}$ & Yes \\
\hline India & $3.15 \times 10^{10}$ & $5.54 \times 10^{10}$ & $2.24 \times 10^{10}$ & $7.65 \times 10^{7}$ & $2.39 \times 10^{10}$ & Yes \\
\hline Indonesia & $7.21 \times 10^{10}$ & $4.23 \times 10^{10}$ & 0 & $2.98 \times 10^{10}$ & $-2.98 \times 1010$ & No \\
\hline $\begin{array}{l}\text { Iran, Islamic } \\
\text { Rep. }\end{array}$ & $2.15 \times 10^{11}$ & $2.07 \times 10^{11}$ & $3.99 \times 10^{9}$ & $1.16 \times 10^{10}$ & $-7.65 \times 10^{9}$ & No \\
\hline Iraq & $1.27 \times 10^{9}$ & $2.63 \times 10^{9}$ & $1.36 \times 10^{9}$ & 0 & $1.36 \times 10^{9}$ & Yes \\
\hline Israel & $9.83 \times 10^{9}$ & $10.00 \times 10^{9}$ & $5.10 \times 10^{8}$ & 0 & $5.10 \times 10^{8}$ & Yes \\
\hline Jordan & $1.22 \times 10^{8}$ & $5.24 \times 10^{9}$ & $6.46 \times 10^{9}$ & $1.36 \times 10^{9}$ & $5.10 \times 10^{9}$ & Yes \\
\hline Kazakhstan & $2.24 \times 10^{10}$ & $1.54 \times 10^{10}$ & $5.75 \times 10^{9}$ & $1.28 \times 10^{10}$ & $-7.05 \times 10^{9}$ & No \\
\hline Kuwait & $1.71 \times 10^{10}$ & $2.17 \times 10^{10}$ & $5.13 \times 10^{9}$ & 0 & $5.13 \times 10^{9}$ & Yes \\
\hline
\end{tabular}


Continued Table A3

\begin{tabular}{|c|c|c|c|c|c|c|}
\hline Country & $\begin{array}{l}\text { Production } \\
\text { (in 2017) }\end{array}$ & $\begin{array}{l}\text { Consumption } \\
\quad \text { (in 2017) }\end{array}$ & $\begin{array}{l}\text { Exports } \\
\text { (in 2017) }\end{array}$ & $\begin{array}{l}\text { Imports } \\
\text { (in 2017) }\end{array}$ & $\begin{array}{l}\text { Net imports } \\
\text { (in 2017) }\end{array}$ & $\begin{array}{c}\text { Net } \\
\text { importing } \\
\text { country } \\
\text { (in 2017) }\end{array}$ \\
\hline $\begin{array}{l}\text { Kyrgyz } \\
\text { Republic }\end{array}$ & $2.83 \times 10^{7}$ & $1.87 \times 10^{8}$ & $1.70 \times 10^{8}$ & 0 & $1.70 \times 10^{8}$ & Yes \\
\hline Lao PDR & 0 & 0 & 0 & 0 & 0 & - \\
\hline Latvia & 0 & $1.22 \times 10^{9}$ & $1.25 \times 10^{9}$ & 0 & $1.25 \times 10^{9}$ & Yes \\
\hline Lebanon & 0 & 0 & 0 & 0 & 0 & - \\
\hline Lithuania & 0 & $2.49 \times 10^{9}$ & $2.49 \times 10^{9}$ & 0 & $2.49 \times 10^{9}$ & Yes \\
\hline $\begin{array}{l}\text { Macedonia, } \\
\text { FYR }\end{array}$ & 0 & $1.98 \times 10^{8}$ & $1.98 \times 10^{8}$ & 0 & $1.98 \times 10^{8}$ & Yes \\
\hline Malaysia & $6.95 \times 10^{10}$ & $3.04 \times 10^{10}$ & $2.80 \times 10^{9}$ & $3.82 \times 10^{10}$ & $-3.54 \times 10^{11}$ & No \\
\hline Maldives & 0 & 0 & 0 & 0 & 0 & - \\
\hline Moldova & $1.13 \times 10^{7}$ & $2.52 \times 10^{9}$ & $2.52 \times 10^{9}$ & 0 & $2.52 \times 10^{9}$ & Yes \\
\hline Mongolia & 0 & 0 & 0 & 0 & 0 & - \\
\hline Myanmar & $1.84 \times 10^{10}$ & $4.50 \times 10^{9}$ & 0 & $1.41 \times 10^{10}$ & $-1.41 \times 10^{10}$ & No \\
\hline Nepal & 0 & 0 & 0 & 0 & 0 & - \\
\hline Oman & $3.12 \times 10^{10}$ & $2.19 \times 10^{10}$ & $1.98 \times 10^{9}$ & $1.12 \times 10^{10}$ & $-9.2 \times 10^{9}$ & No \\
\hline Pakistan & $3.91 \times 10^{10}$ & $4.51 \times 10^{10}$ & $6.00 \times 10^{9}$ & 0 & $6.00 \times 10^{9}$ & Yes \\
\hline Philippines & $3.06 \times 10^{9}$ & $3.14 \times 10^{9}$ & 0 & 0 & 0 & - \\
\hline Poland & $5.75 \times 10^{9}$ & $2.01 \times 10^{10}$ & $1.57 \times 10^{10}$ & $1.25 \times 10^{9}$ & $1.45 \times 10^{10}$ & Yes \\
\hline Qatar & $1.66 \times 10^{11}$ & $3.99 \times 10^{10}$ & 0 & $1.27 \times 10^{11}$ & $-1.27 \times 10^{11}$ & No \\
\hline Romania & $1.09 \times 10^{10}$ & $1.16 \times 10^{10}$ & $1.22 \times 10^{9}$ & $2.27 \times 10^{7}$ & $1.20 \times 10^{9}$ & Yes \\
\hline $\begin{array}{l}\text { Russian } \\
\text { Federation }\end{array}$ & $6.66 \times 10^{11}$ & $4.68 \times 10^{11}$ & $1.58 \times 10^{10}$ & $2.10 \times 10^{11}$ & $-1.94 \times 10^{11}$ & No \\
\hline Saudi Arabia & $1.09 \times 10^{11}$ & $1.09 \times 10^{11}$ & 0 & 0 & 0 & - \\
\hline Serbia & $5.10 \times 10^{8}$ & $2.72 \times 10^{9}$ & $2.01 \times 10^{9}$ & 0 & $2.01 \times 10^{9}$ & Yes \\
\hline Singapore & 0 & $1.30 \times 10^{10}$ & $1.53 \times 10^{10}$ & $6.23 \times 10^{8}$ & $1.29 \times 10^{10}$ & Yes \\
\hline $\begin{array}{l}\text { Slovak } \\
\text { Republic }\end{array}$ & $1.05 \times 10^{8}$ & $4.67 \times 10^{9}$ & $4.98 \times 10^{9}$ & 0 & $4.98 \times 10^{9}$ & Yes \\
\hline Slovenia & $8.00 \times 10^{6}$ & $9.06 \times 10^{8}$ & $9.06 \times 10^{8}$ & $2.83 \times 10^{6}$ & $9.03 \times 10^{8}$ & Yes \\
\hline Sri Lanka & 0 & 0 & 0 & 0 & 0 & - \\
\hline Tajikistan & $1.98 \times 10^{7}$ & $1.98 \times 10^{7}$ & 0 & 0 & 0 & - \\
\hline Thailand & $3.86 \times 10^{10}$ & $5.26 \times 10^{10}$ & $1.44 \times 10^{10}$ & 0 & $1.44 \times 10^{10}$ & Yes \\
\hline
\end{tabular}


End of Table A3

\begin{tabular}{|l|c|c|c|c|c|c|}
\hline \multicolumn{1}{|c|}{ Country } & $\begin{array}{c}\text { Production } \\
\text { (in 2017) }\end{array}$ & $\begin{array}{c}\text { Consumption } \\
\text { (in 2017) }\end{array}$ & $\begin{array}{c}\text { Exports } \\
\text { (in 2017) }\end{array}$ & $\begin{array}{c}\text { Imports } \\
\text { (in 2017) }\end{array}$ & $\begin{array}{c}\text { Net imports } \\
\text { (in 2017) }\end{array}$ & $\begin{array}{c}\text { Net } \\
\text { importing } \\
\text { country } \\
\text { (in 2017) }\end{array}$ \\
\hline Turkey & $3.68 \times 10^{8}$ & $5.36 \times 10^{10}$ & $5.51 \times 10^{10}$ & $6.23 \times 10^{8}$ & $5.45 \times 10^{10}$ & Yes \\
\hline Ukraine & $1.97 \times 10^{10}$ & $3.09 \times 10^{10}$ & $1.30 \times 10^{10}$ & 0 & $1.30 \times 10^{10}$ & Yes \\
\hline $\begin{array}{l}\text { United Arab } \\
\text { Emirates }\end{array}$ & $6.2 \times 10^{10}$ & $7.45 \times 10^{10}$ & $2.02 \times 10^{10}$ & $7.50 \times 10^{9}$ & $1.27 \times 10^{10}$ & Yes \\
\hline Vietnam & $8.1 \times 10^{9}$ & $8.10 \times 10^{9}$ & 0 & 0 & 0 & - \\
\hline Yemen, Rep. & $4.81 \times 10^{8}$ & $4.81 \times 10^{8}$ & 0 & 0 & 0 & - \\
\hline
\end{tabular}

Note: The data was in 2017 and was downloaded from the Central Intelligence Agency (https://www. cia.gov/).

Table A4. The correlation between ED and ECD among B\&R countries

\begin{tabular}{|c|c|c|c|c|}
\hline \multirow{2}{*}{ Year } & \multicolumn{2}{|c|}{ Crude oil } & \multicolumn{2}{c|}{ Natural gas } \\
\cline { 2 - 5 } & Correlation & P Value & Correlation & P Value \\
\hline 2002 & 0.136 & 0.005 & 0.058 & 0.020 \\
\hline 2003 & 0.076 & 0.015 & 0.086 & 0.011 \\
\hline 2004 & 0.106 & 0.005 & 0.111 & 0.005 \\
\hline 2005 & 0.077 & 0.018 & 0.220 & 0.000 \\
\hline 2006 & 0.060 & 0.027 & 0.102 & 0.011 \\
\hline 2007 & 0.082 & 0.009 & 0.274 & 0.000 \\
\hline 2008 & 0.223 & 0.000 & 0.244 & 0.000 \\
\hline 2009 & 0.203 & 0.000 & 0.254 & 0.000 \\
\hline 2010 & 0.232 & 0.000 & 0.161 & 0.001 \\
\hline 2011 & 0.148 & 0.002 & 0.174 & 0.000 \\
\hline 2012 & 0.223 & 0.000 & 0.203 & 0.000 \\
\hline 2013 & 0.239 & 0.000 & 0.221 & 0.000 \\
\hline 2014 & 0.215 & 0.000 & 0.183 & 0.000 \\
\hline 2015 & 0.250 & 0.000 & 0.156 & 0.000 \\
\hline
\end{tabular}




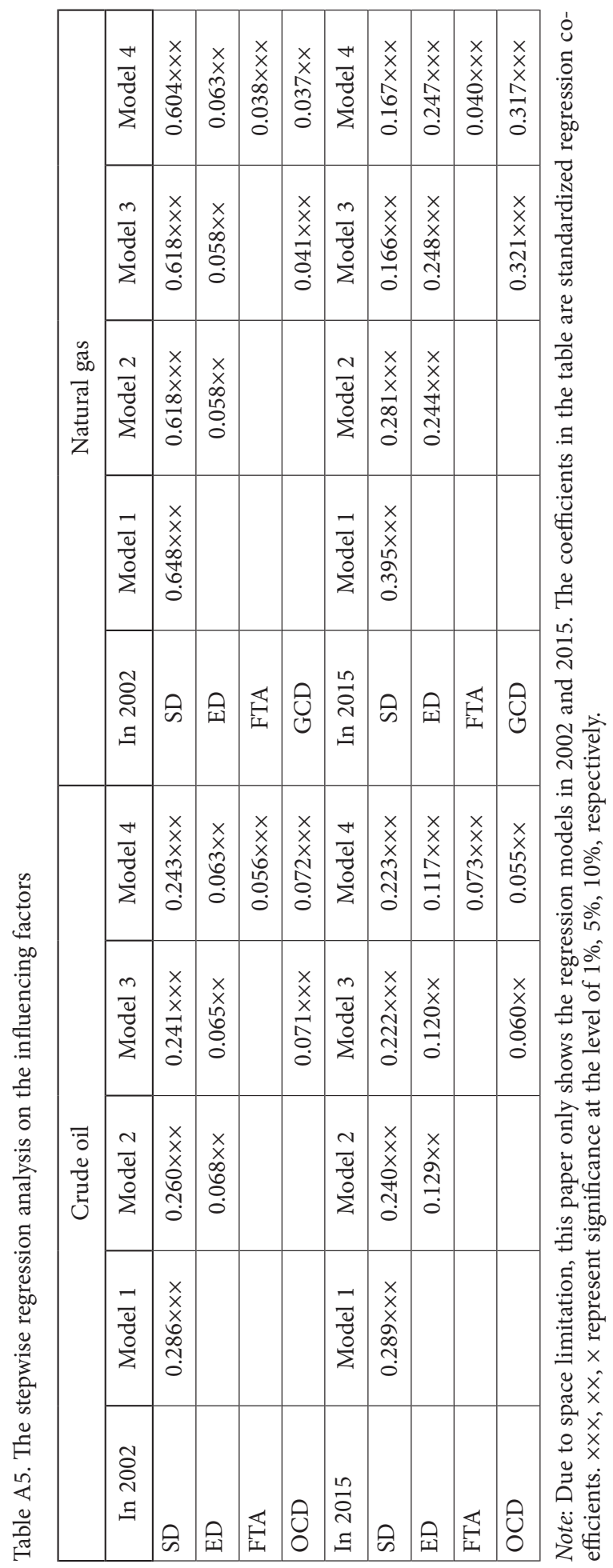

